\title{
Basal melting and freezing under the Amery Ice Shelf, East Antarctica
}

\author{
Jiahong WEN, ${ }^{1}$ Yafeng WANG, ${ }^{1,2}$ Weili WANG, ${ }^{3}$ K.C. JEZEK, ${ }^{4}$ \\ Hongxing LIU, ${ }^{5}$ I. ALLISON ${ }^{6}$ \\ ${ }^{1}$ Department of Geography, Shanghai Normal University, Shanghai 200234, China \\ E-mail: jhwen@shnu.edu.cn \\ ${ }^{2}$ Information Centre of Library, Jiangsu University of Science and Technology, Zhenjiang, Jiangsu 212003, China \\ ${ }^{3}$ SGT, Inc., NASA Goddard Space Flight Center, Code 614.1, Greenbelt, Maryland 20771, USA \\ ${ }^{4}$ Byrd Polar Research Center, The Ohio State University, 1090 Carmack Road, Columbus, Ohio 43210-1002, USA \\ ${ }^{5}$ Department of Geography, University of Cincinnati, Cincinnati, Ohio 45221-0131, USA \\ ${ }^{6}$ Australian Antarctic Division and Antarctic Climate and Ecosystems CRC, Hobart, Tasmania 7001, Australia
}

\begin{abstract}
The basal melting and freezing rates under the Amery Ice Shelf, East Antarctica, are evaluated, and their spatial distributions mapped. Ice velocity, surface elevation and accumulation rate datasets are employed in the analysis, along with a column-averaged ice density model. Our analysis shows that the total area of basal melting is $34700 \mathrm{~km}^{2}$, with a total annual melt of $62.5 \pm 9.3 \mathrm{Gt}$ and an average melting rate of $1.8 \pm 0.3 \mathrm{~m} \mathrm{a}^{-1}$. Basal freezing mainly occurs in the northwestern part of the ice shelf, over a total area of $26100 \mathrm{~km}^{2}$ and with a maximum freezing rate of $2.4 \pm 0.4 \mathrm{~m} \mathrm{a}^{-1}$. The total marine ice that accretes to the ice-shelf base is estimated to be $16.2 \pm 2.4 \mathrm{Gta}^{-1}$. Using a redefined grounding line and geometry of the Amery Ice Shelf, we estimate the net melt over the ice-shelf base is about $46.4 \pm 6.9 \mathrm{Gt} \mathrm{a}^{-1}$, which is higher than previous modeling and oceanographic estimates. Net basal melting accounts for about half of the total ice-shelf mass loss, with the rest being from iceberg discharge. Our basal melting and freezing distribution map provides a scientific basis for quantitative analysis of ice-ocean interaction at the ice-shelf-ocean interface.
\end{abstract}

\section{INTRODUCTION}

Global climate change has a great impact on ice shelves, because they are sensitive to changes in air and ocean temperature or circulation near Antarctica. The break-up of ice shelves in the Antarctic Peninsula is regarded as a signal of regional climate change (Vaughan and Doake, 1996). The area of the ice shelves around the Antarctic Peninsula has shrunk by $>12500 \mathrm{~km}^{2}$ over the past three decades (Scambos and others, 2003; Domack and others, 2005), resulting in the acceleration and thinning of tributary glaciers (De Angelis and Skvarca, 2003; Rignot and others, 2004; Scambos and others, 2004). Intrusion of warmer ocean water beneath the ice shelves in the Amundsen Sea sector of West Antarctica increased basal melting, resulting in ice-shelf thinning (Shepherd and others, 2004) and the accelerated discharge of inland ice mass towards the ocean (e.g. Rignot, 1998, 2001; Payne and others, 2004; Shepherd and others, 2004; Thomas and others, 2004). This may lead to the instability of the West Antarctic ice sheet, which is grounded on bedrock below sea level (Oppenheimer, 1998; Payne and others, 2004). Understanding the dynamics of ice shelves and their interaction with ocean is therefore fundamentally important for predicting the contribution of the Antarctic ice sheet to future global sea-level rise (Pritchard and others, 2009). In this study, we examine the basal melt/freeze pattern of the Amery Ice Shelf which is fed by one of the largest glacier systems in East Antarctica.

The Amery Ice Shelf is the largest ice shelf in East Antarctica and drains the grounded ice of the Lambert Glacier/Amery Ice Shelf system. Scientific investigation of the Amery Ice Shelf began in the mid-1950s (Mellor and McKinnon, 1960). A series of surveys on the ice shelf and the ocean cavity beneath the shelf and in Prydz Bay have subsequently investigated ice-shelf dynamics and mass budget and the ice/ocean interaction, including patterns of melting and freezing at the base of the ice shelf (e.g. Morgan, 1972; Budd and others, 1982; Fricker and others, 2001, 2002; Allison, 2003; King and others, 2007, 2009; Galton-Fenzi and others, 2008; Craven and others, 2009).

Melting and freezing beneath the Amery Ice Shelf have also been studied using numerical ocean models and hydrographic observations. Hellmer and Jacobs (1992) reported a mean melting rate as high as $0.65 \mathrm{ma}^{-1}$ by modeling the sub-Amery ocean thermohaline circulation. This melt rate is equivalent to the removal of $23 \mathrm{Gta}^{-1}$ of basal ice. Using a three-dimensional (3-D) numerical ocean model, Williams and others (2001) simulated the ocean cavity beneath the Amery Ice Shelf and obtained net melting rates of 5.8 and $18.0 \mathrm{Gta}^{-1}$ for two different boundary conditions. Both model simulations also showed regions of basal freezing under the ice shelf, with marine ice accretion of several $\mathrm{Gta}^{-1}$. Based on hydrographic observations collected near the front of the Amery Ice Shelf, Wong and others (1998) reported that the net amount of ice loss from the ice-shelf bottom ranged from 10.7 to $21.9 \mathrm{Gt} \mathrm{a}^{-1}$. Using a coupled ice/ocean model, Hellmer (2004) estimated the spatial average basal melting rate $\left(0.35 \mathrm{~m} \mathrm{a}^{-1}\right)$ and total basal mass loss $\left(17.65 \mathrm{Gt} \mathrm{a}^{-1}\right)$ for the Amery Ice Shelf.

In the upper reaches of the ice shelf, the southern grounding line (Fig. 1) was redefined from a hydrostatic equilibrium model (Fricker and others, 2002) and interferometric synthetic aperture radar (InSAR) analysis (Rignot, 2002). This grounding line extends the Amery Ice Shelf by $\sim 240 \mathrm{~km}$ upstream, compared with the grounding line position reported by Budd and others (1982). Using InSAR techniques, Rignot and Jacobs (2002) estimated a melt rate 


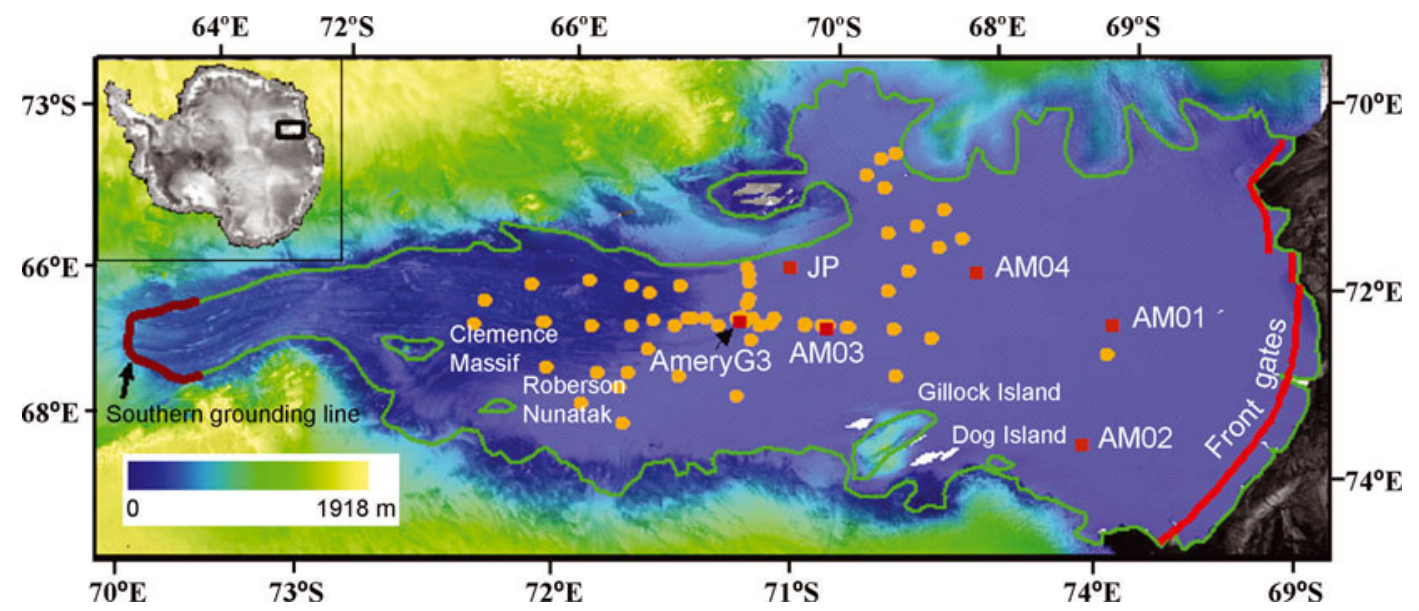

Fig. 1. Location of the Amery Ice Shelf, Antarctica (black box in inset). The green curves show the outline of the ice shelf and four ice rises, and the front of the ice shelf as defined by the RAMP synthetic aperture radar (SAR) image mosaic acquired in 1997 (background image: Jezek, 1999). The dark red curve shows the southern grounding line. The light red curves show the gates where ice flux across the ice front was calculated. The orange dots are GPS stations occupied during the 1988-99 GPS campaigns (King, 2002, table 5-12), and the red squares are locations mentioned in the text. The color shading (scale lower left) shows the GLAS/ICESat $500 \mathrm{~m}$ digital elevation model (J. DiMarzio and others, http://nsidc.org/data/nsidc-0304.html).

of $31 \pm 5 \mathrm{~m}$ ice $^{-1}$ near the southern grounding line. Using remote-sensing datasets and in situ measurements, Wen and others (2007) reported the change in pattern of basal mass flux from the southern grounding line to the ice-shelf front along the flowbands of Lambert, Mellor and Fisher glaciers. From in situ borehole temperature and salinity measurements at AM02 (Fig. 1), Craven and others (2004) estimated a minimum melt rate of $0.5 \mathrm{~m} \mathrm{a}^{-1}$ at the ice-shelf base at that location. However, a complete basal melting- and freezingrate distribution over the entire ice shelf has not been reported in these previous studies.

In this paper, various remote-sensing datasets and in situ measurements have been assimilated in a Geographic Information System environment to map and analyze the basal melting/freezing patterns over the entire Amery Ice Shelf. The calving front of the Amery Ice Shelf was defined from the RADARSAT-1 Antarctic Mapping Project (RAMP) image mosaic derived in 1997 (Jezek, 1999; Fig. 1). The grounding line of the ice shelf (Fig. 1) is based on that of Fricker and others (2002), and further improved by incorporating the southern grounding line position mapped by the InSAR technique (Rignot, 2002), and the grounding line extracted by identifying the surface slope breaks between the grounded ice sheet and the floating ice shelf in Moderate Resolution Imaging Spectroradiometer (MODIS) images (personal communication from N. Young, 2009). The slope breaks are on the landward side of the grounding zone, and define the southern boundary of the ice shelf. The original polar stereographic projection was transformed to the Lambert azimuthal equal-area projection to calculate the area of the Amery Ice Shelf. The area is estimated to be $60785 \mathrm{~km}^{2}$, which is similar to the area estimate of GaltonFenzi and others (2008).

Glaciological volume conservation methods (e.g. Jenkins and Doake, 1991; Joughin and Padman, 2003) were employed and are discussed below. Based on the recent remote-sensing data, we find that net melting accounts for about $50 \%$ of the total mass loss of the ice shelf, which is far greater than a typical ratio (about $30 \%$ ) of the basal melting to the total mass loss for ice shelves (Jacobs and others, 1996). Basal melting and freezing under the Amery Ice Shelf play a critical role in the ice-shelf mass balance, and the interaction at the ice/ocean interface beneath the ice shelf may be more intensive than was thought previously.

\section{METHODS}

The basal melting and freezing calculation is based on the assumption that the ice shelf is in a steady balance. A recent study by King and others (2009) suggests that the surface elevation (and hence thickness) has not changed significantly over four decades since 1968. Although short-term fluctuations of an elevation magnitude less than $1.0 \mathrm{~m}$ may exist, the ice shelf has been almost in balance over the longer term.

The ice mass conservation can be expressed as

$$
\frac{\partial Z}{\partial t}+\nabla \cdot(Z V)=\dot{a}-\dot{b},
$$

where $Z$ is the thickness of the ice shelf, $V$ is the horizontal velocity, $\nabla$ is the two-dimensional gradient operator, $\dot{a}$ is the surface net accumulation rate and $\dot{b}$ is the basal melting/ freezing rate (negative for basal freezing). When the ice shelf is in steady state $(\partial Z / \partial t=0)$, the horizontal divergence of the volume flux is exactly balanced by the sum of surface accumulation and basal melting/freezing rates. The equilibrium basal melting/freezing rate can then be expressed as

$$
\dot{b}=\dot{a}-\nabla \cdot(Z V) \text {. }
$$

For a floating ice shelf, the ice-flow speed and direction at any depth can be assumed to be the same as at the surface (Budd, 1966). For an ice column in steady state, the total ice inflow into the column is equal to the total outflow from mass conservation (e.g. Jenkins and Doake, 1991). Thus, for an ice column with surface area $S, x$-direction ice fluxes $\Phi_{x}$ and $\Phi_{x+\Delta x}$, and $y$-direction ice fluxes $\Phi_{y}$ and $\Phi_{y+\Delta y}$ Equation (2) can be expressed as

$$
\dot{b}=\dot{a}-\frac{\left(\Phi_{x+\Delta x}-\Phi_{x}\right)+\left(\Phi_{y+\Delta y}-\Phi_{y}\right)}{S} .
$$

$\Phi_{x}$ and $\Phi_{x+\Delta x}$ are calculated from the thickness $Z$ and the $x$ direction component of ice velocity $V$. Positive values of $\dot{b}$ 
indicate basal melting beneath the ice shelf, and negative values indicate freezing.

Three flux gates normal to the velocity vector were defined at the ice-shelf front (Fig. 1) to calculate the ice discharge and overall mass balance for the ice shelf. The ice flux $\Phi$ across each gate can be calculated as

$$
\Phi=\sum\left(\frac{V_{i} Z_{i} \rho_{i}+V_{i+1} Z_{i+1} \rho_{i+1}}{2}\right) \Delta X
$$

where $i(1,2, \ldots, n)$ is the index for gridcells along the flux gate, $\Delta X$ is the width of gridcells, and $V_{i}, Z_{i}$ and $\rho_{i}$ are respectively ice velocity, ice thickness and column-averaged ice density for gridcell $i$.

The ice thickness is derived by applying the hydrostatic equilibrium equation,

$$
Z_{i}=\frac{\rho_{\mathrm{w}}}{\rho_{\mathrm{w}}-\rho_{i}} H_{i}
$$

where $H_{i}$ is the surface elevation for cell $i, \rho_{\mathrm{w}}$ is the seawater density and other terms are the same as in Equation (4).

\section{DATA}

The datasets used in our basal melting/freezing analysis include (1) InSAR velocity data, (2) surface elevation data, (3) column-averaged ice density, (4) ice-thickness data and (5) annual snow accumulation data.

\section{InSAR velocity}

In 2000, three repeat-cycle InSAR data were acquired by a C-band synthetic aperture radar (SAR) sensor on board the RADARSAT-1 satellite during the second Antarctic Mapping Mission (Jezek, 2002, 2003), also known as the Modified Antarctic Mapping Mission (MAMM). The RADARSAT InSAR data cover the area from the Antarctic coast to $82^{\circ} \mathrm{S}$ (Jezek, 2003, 2008). The velocity measurements (Fig. 2) used in this study are taken from the processed InSAR velocity database (Jezek, 2008; http://bprc.osu.edu/rsl/radarsat/data/) with a gridcell size of $400 \mathrm{~m}$.

In the interferometric processing, velocities have been corrected for the effects of local elevation and tide on floating ice shelves, using the tide model provided by L. Padman (Jezek, 2008). The error sources in the interferometric processing include velocity control point (VCP) errors, imperfect fitting between the baseline offsets and the VCPs, digital elevation model (DEM) errors, phase-unwrapping seed errors, offset error caused by misregistration and phase uncertainty. The combination of these error sources results in a velocity uncertainty estimated to be within $\pm 10 \mathrm{~m} \mathrm{a}^{-1}$ (Jezek, 2003, 2008). See Jezek (2008) for further details of the InSAR velocity data processing.

King and others (2007) found an apparent systematic bias in InSAR velocity (Joughin, 2002; Young and Hyland, 2002) up to $\pm 30-40 \mathrm{ma}^{-1}$, compared to velocities determined from global positioning system (GPS) and traditional survey. King (2002) compiled 70 GPS observations over the Amery Ice Shelf over the period 1988-99. Of these, 49 sites have velocity measurements, $V_{\mathrm{GPS}}$ (Fig. 2c). The precision $(1 \sigma)$ of the GPS velocities is $2.2 \mathrm{~m} \mathrm{a}^{-1}$ for the 1988-91 data and $0.9 \mathrm{~m} \mathrm{a}^{-1}$ for the 1995-99 data (King, 2002; King and others, 2007). We have compared these GPS velocity measurements with the InSAR velocities $\left(V_{\text {InSAR }}\right)$, and the statistics of the differences between GPS and InSAR
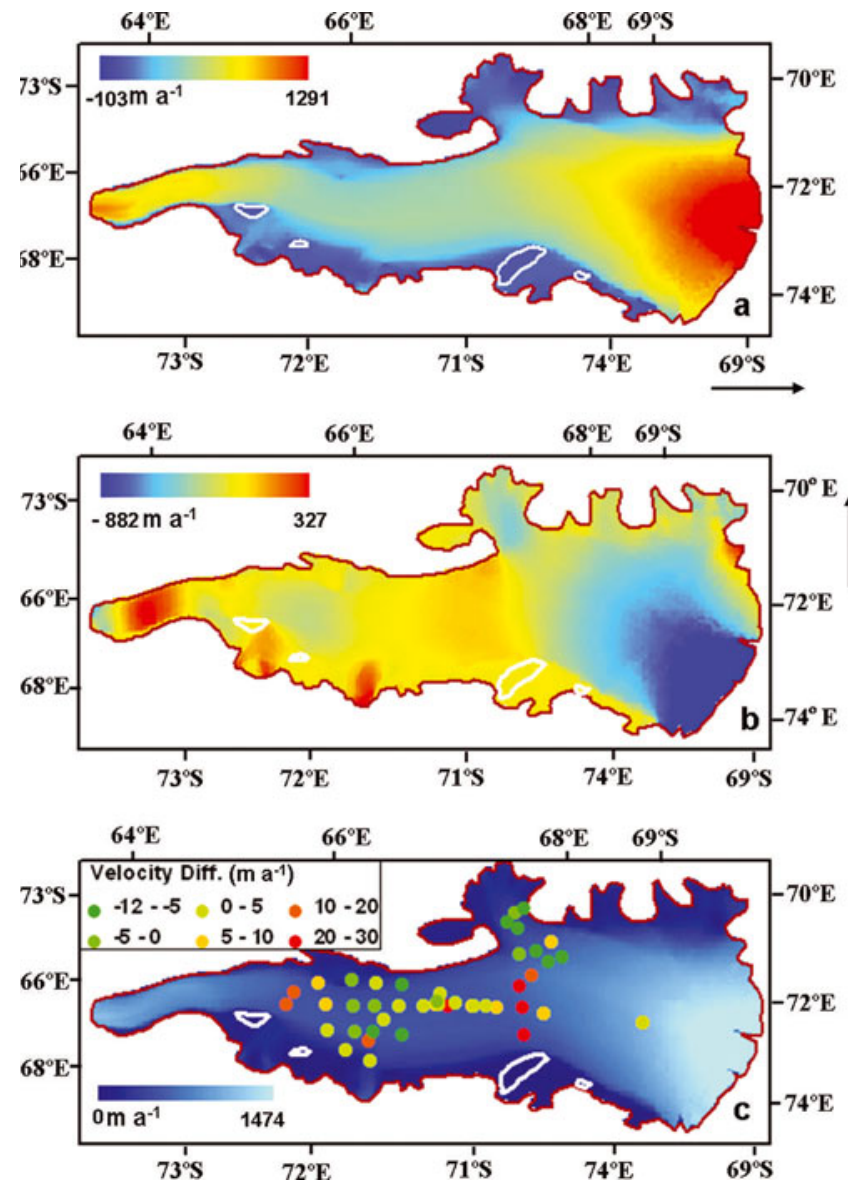

Fig. 2. (a) $x$ component and (b) $y$ component of the InSAR velocity on the Amery Ice Shelf; and (c) total velocity. The arrows define directions of the $x$ and $y$ components. Colored dots in (c) indicate the differences between GPS and InSAR velocities.

measurements are summarized in Table 1. The maximum difference is up to $30 \mathrm{~m} \mathrm{a}^{-1}$, and the mean difference is $4.41 \pm 9.7 \mathrm{~m} \mathrm{a}^{-1}$.

\section{Surface elevation data}

Previous studies show that marine ice accretion occurs under the base of the Amery Ice Shelf through basal freezing processes, and the marine ice area accounts for $40 \%$ of the ice shelf, mostly in the northwestern part (Fricker and others, 2001; Wang and others, 2006). Airborne radio-echo sounding (RES) signals may not penetrate the marine ice layer (Fricker and others, 2001), so the ice thickness measured by RES may exclude the marine ice layer. In this study, the surface elevation data were used to estimate the ice thickness based on the assumption of hydrostatic equilibrium of the floating ice shelf (Joughin and Padman, 2003).

There are several DEMs available for our study area. The Amery Ice Shelf DEM (AIS-DEM; Fricker and others, 2000) generated from European Remote-sensing Satellite (ERS-1) altimeter data collected between April 1994 and March 1995 has a $1000 \mathrm{~m}$ gridcell size and a vertical uncertainty of $1.7 \mathrm{~m}$ (root-mean-square (rms) error). The Geoscience Laser Altimeter System (GLAS)/Ice, Cloud and land Elevation Satellite (ICESat) laser altimetry DEM of Antarctica (ICESatDEM) was generated from the ICESat laser observations during the first seven operational periods (February 2003June 2005; J. DiMarzio and others, http://nsidc.org/data/ nsidc-0304.html). This DEM has a $500 \mathrm{~m}$ grid spacing and is 
Table 1. Differences between GPS measured velocities and InSAR velocities $\left(\mathrm{m} \mathrm{a}^{-1}\right)$

\begin{tabular}{lccccc}
\hline$V_{\mathrm{GPS}}$ No. & Average $V_{\mathrm{GPS}}$ & Average $V_{\mathrm{InSAR}}$ & Min. $V_{\mathrm{GPS}}-V_{\mathrm{InSAR}}$ & Max. $V_{\mathrm{GPS}}-V_{\mathrm{InSAR}}$ & Average $V_{\mathrm{GPS}}-V_{\mathrm{InSAR}}$ \\
\hline 49 & 372.7 & 368.3 & -11.9 & 30.0 & 10.7 \\
\hline
\end{tabular}

referenced to the World Geodetic System 1984 (WGS84) ellipsoid. By comparing with aircraft laser altimetry data, the overall vertical accuracy of the ICESat DEM is estimated to be $8 \pm 82 \mathrm{~cm}$, varying as a function of surface slope (personal communication from J. DiMarzio, 2009).

We used 70 GPS elevation data points (Fig. 1) from King (2002, table 5-12) to validate and compare these two DEMs. The elevation values of the AIS-DEM, which are originally referenced to the Earth Geopotential Model 1996 (EGM96) geoid, were transformed onto the WGS84 ellipsoid. Both the AIS-DEM and the ICESat-DEM were resampled onto a $400 \mathrm{~m}$ cell-size grid (to match the MAMM InSAR velocity data) using a bilinear interpolation approach. A comparison of GPS elevations, $H_{\mathrm{GPS}}$, with corresponding gridcell elevations from the DEMs, $H_{\mathrm{DEM}}$, is summarized in Table 2 . The average error (difference) is $0.21 \mathrm{~m}$ for the ICESat-DEM and $0.67 \mathrm{~m}$ for the AIS-DEM. The rms errors for both DEMs are estimated to be $3.80 \mathrm{~m}$. The elevation of the AIS-DEM is on average $0.47 \mathrm{~m}$ lower than that of the ICESat-DEM. Given the different data collection periods for the two DEMs, this is in agreement with King and others (2009) who showed that the ice shelf was $\sim 0.8 \mathrm{~m}$ higher on average in 2003 than in 1995 .

\section{Column-averaged ice density}

Fricker and others (2001) examined the column-averaged ice density over the Amery Ice Shelf using a two-layer density model. However, the density values from this model may be lower than actual values due to an underestimate of the marine ice density. The marine ice contains sea-water cells, and its average density is up to $938 \mathrm{~kg} \mathrm{~m}^{-3}$ (Craven and others, 2009). As a result, the inferred maximum marine ice thickness of $190 \mathrm{~m}$ in Fricker and others (2001) is smaller than the actual borehole measurements (Craven and others, 2004, 2005). Combining the AIS-DEM, in situ GPS elevations, RES ice thickness, and borehole and ice-core measurements, Wen and others (2007) modeled the column-averaged ice density of the Amery Ice Shelf for three separate sections. In their model, the ice columnaveraged density along the upstream section (0-215 km from the southern grounding line) decreases linearly from 921 to $914.7 \mathrm{~kg} \mathrm{~m}^{-3}$. Along the middle section $(215-315 \mathrm{~km})$, it decreases linearly from 914.7 to $903.5 \mathrm{~kg} \mathrm{~m}^{-3}$, and along the downstream section (from $315 \mathrm{~km}$ to the ice-shelf front) it decreases from 903.5 to $890.5 \mathrm{~kg} \mathrm{~m}^{-3}$. At AM01, the marine ice thickness using the density from Fricker and others (2001) is estimated to be $141 \pm 30 \mathrm{~m}$ (Craven and others,
2009), while using the density model of Wen and others (2007) it is estimated as $177 \pm 30 \mathrm{~m}$. Both these estimates use the AIS-DEM and Russian airborne RES measurements collected between 1986 and 1995 (Fricker and others, 2001). The estimate using the density model of Wen and others (2007) is closer to the marine ice thickness measured in the borehole at AM01 of $203 \pm 2 \mathrm{~m}$ (Craven and others, 2009). The column-averaged densities at AM01 and AM04 are 896 and $900 \mathrm{~kg} \mathrm{~m}^{-3}$ respectively from the model of Wen and others (2007), slightly less than the values of 898 and $906 \mathrm{~kg} \mathrm{~m}^{-3}$ estimated by Craven and others (2009). Due to its better performance, the density model of Wen and others (2007) is hence used in this paper.

\section{Ice thickness}

The ice-thickness distribution $Z$ is generated from the ICESatDEM surface elevation $H$ by applying the hydrostatic equation (5) with a sea-water density $\rho_{\mathrm{w}}$ of $1028 \mathrm{~kg} \mathrm{~m}^{-3}$ (e.g. Craven and others, 2009) and the above ice density model. The ICESat-DEM was first converted to orthometric heights relative to a Gravity Recovery and Climate Experiment (GRACE)-based static geoid model (EIGEN-GLO4C; http://icgem.gfz-potsdam.de/ICGEM/ICGEM.html). This model has improved the previous global geoid model (with errors up to $\pm 3 \mathrm{~m}$ over the Amery Ice Shelf region) by up to an order of magnitude. There are some small patches near Gillock Island (Fig. 1, patches in white) with missing data in the ICESat-DEM, and the AIS-DEM was used here.

\section{Net surface accumulation}

Annual net surface accumulation data have been compiled by Vaughan and others (1999) and Giovinetto and Zwally (2000) based on essentially the same field measurements collected from the 1950 s to 1990 s, but using different analysis and interpolation criteria. We refer to these as the Vaughan and Giovinetto compilations respectively. The latter was checked and amended (personal communication from M. Giovinetto, 2005) and we refer to this updated version as the modified compilation. These three original accumulation compilations were interpolated onto a $5 \mathrm{~km}$ cell-size grid using the kriging interpolation method. By comparing on a cell-by-cell basis, we find that the modified compilation is similar to the Giovinetto compilation, with a mean difference of $-9 \pm 13 \mathrm{~mm} \mathrm{a}^{-1}$, but rather different from the Vaughan compilation, with a mean difference of $-32 \pm 42 \mathrm{~mm} \mathrm{a}^{-1}$ over the Amery Ice Shelf.

Table 2. Differences between GPS elevations and ICESat- and AIS-DEMs (m)

\begin{tabular}{|c|c|c|c|c|c|c|c|}
\hline & GPS points & Average $Z_{\mathrm{GPS}}$ & Average $Z_{\mathrm{DEM}}$ & Min. $Z_{\text {GPS }}-Z_{\mathrm{DEM}}$ & Max. $Z_{\mathrm{GPS}}-Z_{\mathrm{DEM}}$ & Average $Z_{\mathrm{GPS}}-Z_{\mathrm{DEM}}$ & $\mathrm{rms}$ \\
\hline ICESat-DEM & 70 & 100.40 & 100.19 & -16.50 & 12.72 & 0.21 & 3.80 \\
\hline AIS-DEM & 70 & 100.40 & 99.73 & -11.0 & 8.06 & 0.67 & 3.80 \\
\hline
\end{tabular}




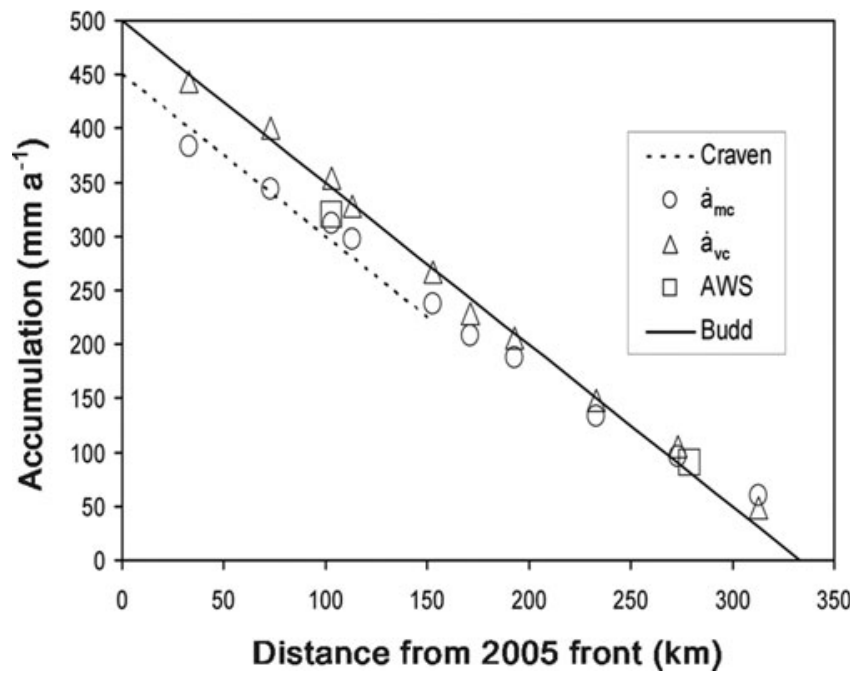

Fig. 3. Accumulation distributions $\left(\mathrm{kg} \mathrm{m}^{-2} \mathrm{a}^{-1}\right)$ as a function of distance from the 2005 front of the Amery Ice Shelf. The solid line is the distribution of Budd and others (1982), and the dashed line is the decreased distribution used by Craven and others (2009) to account for the advance of the ice front by $>30 \mathrm{~km}$. The squares are multi-year accumulation measurements from the AWS at AM01 (103 km from the ice-shelf front) and AmeryG3 $(279 \mathrm{~km}$ from the ice-shelf front). The triangles and circles are the modified $\left(\dot{a}_{\mathrm{mc}}\right)$ and Vaughan $\left(\dot{a}_{\mathrm{vc}}\right)$ compilations respectively.

In situ accumulation rate measurements, $\dot{a}$, for the Amery Ice Shelf are available from stakes and firn-core records from 1968 to 1970 (Budd and others, 1982) and from recent automatic weather station (AWS) measurements. Budd and others (1982) showed an inverse linear dependence of the accumulation rate with distance from the calving ice front, with net accumulation dropping to zero $300 \mathrm{~km}$ from the ocean in Prydz Bay. Since 1968 the front of the Amery Ice Shelf has advanced $>30 \mathrm{~km}$ into Prydz Bay, and Craven and others (2009) adjusted the Budd and others (1982) accumulation distribution near the front of the shelf to lower values in order to account for the presently larger distance to the ice front. This adjustment is supported by accumulation measurements from an AWS that operated for almost 5 years (2002-06) at AM01. Net accumulation at a location further away from the ice-shelf front is influenced not only by the distance to the ocean but also by other factors such as summer melt. An AWS at
AmeryG3 (Fig. 1) has operated for more than 10 years (1999-2008), and the observed net accumulation is very similar to that measured at the same geographic location in the late 1960s.

The above field and AWS measurements are compared with the Vaughan and the Giovinetto modified compilations in Figure 3. We find that the values from the modified compilation, $\dot{a}_{\mathrm{mc}}$, are closer to the field and AWS measurements than the Vaughan compilation, $\dot{a}_{\mathrm{vc}}$. Hence we use the modified Giovinetto compilation for accumulation.

Firn-core records show that accumulation rates have increased since the 1970s on the east side, but decreased on the west side of the Lambert Glacier basin (Xiao and others, 2001). From the decadal-level accumulation variations modeled by Monaghan and others (2006), King and others (2009) inferred that the region around the Amery Ice Shelf experienced a $\sim 5 \%$ reduction in accumulation over the period 1955-95 followed by a $\sim 15 \%$ increase in accumulation over the period 1995-2004.

We estimate an uncertainty of $\pm 50 \mathrm{~mm} \mathrm{a}^{-1}$ in the average accumulation data over decadal periods for the northern part of the Amery Ice Shelf.

\section{DATA PROCESSING AND ERROR ANALYSIS}

We first attempted to calculate the basal melting and freezing rates at a $400 \mathrm{~m}$ cell-size grid. But because of random errors in the velocity and ice-thickness fields, some melting/freezing rates were unrealistically variable and high (up to hundreds of metres per year). Although differences between the GPS and InSAR velocities are mostly $<10 \mathrm{~m} \mathrm{a}^{-1}$, a few differences are $>20 \mathrm{ma}^{-1}$. Errors in ice thickness are due to errors in the DEM and the column-averaged ice density, and while most ICESat-DEM elevations are generally within $\pm 5 \mathrm{~m}$ of the GPS measurements (Fig. 4), a few elevation outliers are up to $10 \mathrm{~m}$ different. Therefore, we calculated the rates over larger areas, rather than the original $400 \mathrm{~m}$ gridcells. We defined 56 squares on the Amery Ice Shelf, each with an area of $25 \mathrm{~km} \times 25 \mathrm{~km}$ (Fig. 5). The use of $25 \mathrm{~km}$ squares as the basic spatial unit for our numerical analysis increases the signal-to-noise ratio through averaging and making each square estimate more reliable. Around the edge of the ice shelf, an additional 20 smaller rectangles were defined so that the basal melting and freezing data have a relatively homogeneous distribution over the entire ice shelf (Fig. 5). In order to test the sensitivity to square size,
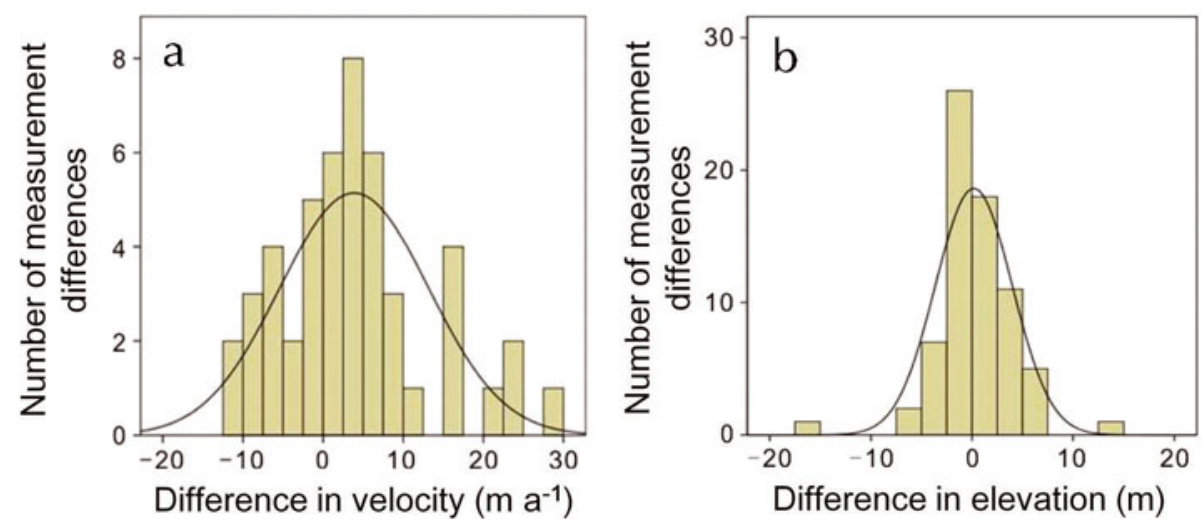

Fig. 4. Histograms and normal distribution of number of differences between the GPS and InSAR velocities (a), and between the ICESat-DEM elevations (b). 


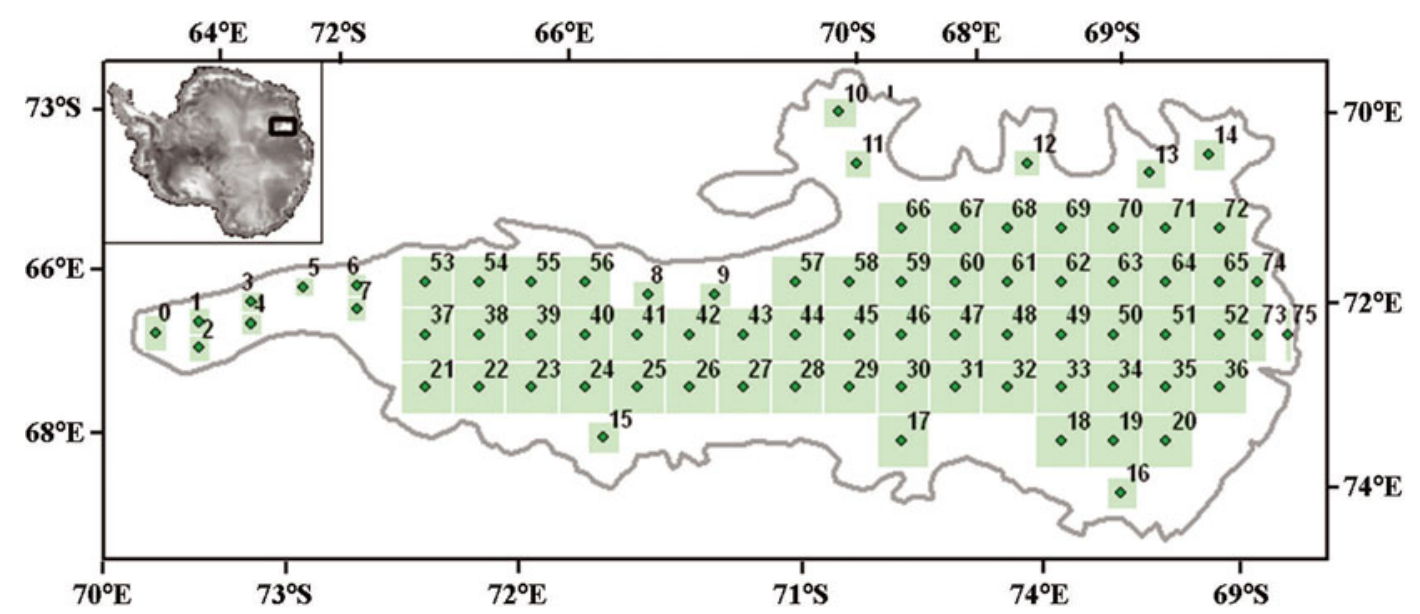

Fig. 5. Numbered areas for the calculation of the basal melting and freezing rates under the Amery Ice Shelf (see Table 3).

we also calculated the basal melting rates on $20 \mathrm{~km} \times 20 \mathrm{~km}$ squares as discussed below.

For each square we determined the fluxes in both the $x$ and $y$ directions (Equation (3)) from the averaged ice velocity and thickness values along each side of the square and converted the melting/freezing rates to water equivalent. The four ice rises were excluded from our calculation (Fig. 1).

The basal melting and freezing rates, $\dot{b}$, for the 76 defined squares and rectangles on the Amery Ice Shelf are calculated using Equation (3). The $\dot{b}$ value shown in Table 3 is assigned to the geometrical center of each square or rectangle. The spatial distributions of the melting/freezing rates beneath the Amery Ice Shelf shown in Figure 6 were obtained by interpolating the $76 \dot{b}$ points (Table 3) together with $18 \dot{b}$ points along flowbands originating from Lambert, Mellor and Fisher glaciers from a previous study of Wen and others (2007). The additional $18 \dot{b}$ points from Wen and others (2007) were calculated using the AIS-DEM and the same velocity data and density model. These $\dot{b}$ values have a similar uncertainty to the present study. They are used to supplement melting rates near the ice front and the southern grounding line areas. The interpolation was made using an ordinary kriging method in ArcGIS, and the interpolation result is a smooth melting/freezing rate grid with a $400 \mathrm{~m}$ cell size. The empirical variogram was modeled as an exponential function that was applied when spatial autocorrelation decreases exponentially with increasing distance. This function may provide the best fit through the points as the melting rates decrease rapidly downstream from the southern grounding line. The fit parameters were: number of lags $=12$, range $=35000 \mathrm{~m}$ and nugget $=0.1 \mathrm{~m} \mathrm{a}^{-1}$. A quadrant neighborhood was defined to enclose the points used to predict values at unmeasured locations, and in each quadrant/sector of the search neighborhood a maximum of five and a minimum of two data points were used to contribute to an interpolated value.

We assess the errors and their propagation in our calculation of basal melting and freezing rates. The main error sources involved in calculating the ice thickness $Z$ are errors in the column-averaged ice density $\rho_{i}$ and the ICESatDEM elevation $H$. The relative error, $\Delta Z / Z$, in ice thickness is approximated by

$$
\frac{\Delta \mathrm{Z}}{\mathrm{Z}} \approx\left\{\left(\frac{\Delta H}{H}\right)^{2}+\left[\frac{\left(\Delta \rho_{\mathrm{w}}^{2}+\Delta \rho_{i}^{2}\right)^{\frac{1}{2}}}{\left(\rho_{\mathrm{w}}-\rho_{i}\right)}\right]^{2}\right\}^{\frac{1}{2}}
$$

where elevations are typically $\sim 100 \mathrm{~m}$, and accurate to better than $3 \mathrm{~m}$ with the improved geoid model. The average density of the ice column is typically $908 \mathrm{~kg} \mathrm{~m}^{-3}$ and has an

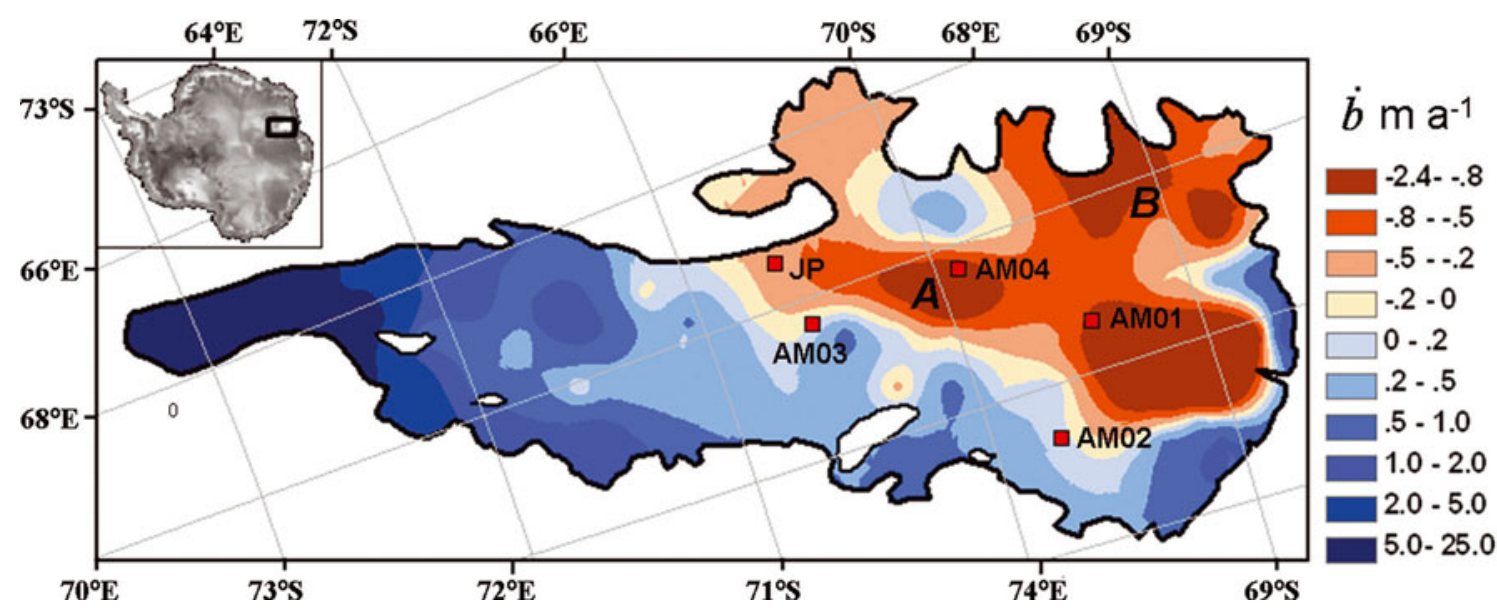

Fig. 6. Spatial distribution of the basal melting/freezing rates $\left(\mathrm{m} \mathrm{a}^{-1}\right)$ beneath the Amery Ice Shelf. Red/brown colors show the basal freezing area, and blue colors show basal melting areas. Two longitudinal bands of the maximum freezing rates are marked with A and B. 
Table 3. Basal melting rates, $\dot{b}$, under the Amery Ice Shelf. Negative values indicate freezing (marine ice accretion)

\begin{tabular}{|c|c|c|c|c|c|c|c|}
\hline ID & $\begin{array}{l}\text { Lat. } \\
{ }^{\circ} \mathrm{S}\end{array}$ & $\begin{array}{c}\text { Long. } \\
{ }^{\circ} \mathrm{E}\end{array}$ & $\begin{array}{c}\dot{b} \\
\mathrm{ma}^{-1}\end{array}$ & ID & $\begin{array}{l}\text { Lat. } \\
{ }^{\circ} \mathrm{S}\end{array}$ & $\begin{array}{c}\text { Long. } \\
{ }^{\circ} \mathrm{E}\end{array}$ & $\begin{array}{c}\dot{b} \\
\mathrm{ma}^{-1}\end{array}$ \\
\hline 0 & 73.1940 & 67.1713 & 24.96 & 38 & 71.9210 & 68.9106 & 0.70 \\
\hline 1 & 73.0060 & 67.2595 & 7.32 & 39 & 71.7113 & 69.1678 & 0.36 \\
\hline 2 & 73.0490 & 67.6141 & 11.24 & 40 & 71.5014 & 69.4191 & 1.29 \\
\hline 3 & 72.7671 & 67.2996 & 7.43 & 41 & 71.2912 & 69.6647 & 0.57 \\
\hline 4 & 72.8024 & 67.5864 & 8.35 & 42 & 71.0808 & 69.9048 & 0.18 \\
\hline 5 & 72.5383 & 67.3974 & 8.94 & 43 & 70.8703 & 70.1394 & 0.32 \\
\hline 6 & 72.3274 & 67.6567 & 4.55 & 44 & 70.6595 & 70.3689 & -0.09 \\
\hline 7 & 72.3658 & 67.9675 & 7.76 & 45 & 70.4486 & 70.5933 & 0.66 \\
\hline 8 & 71.1891 & 69.2154 & -0.08 & 46 & 70.2375 & 70.8129 & 0.09 \\
\hline 9 & 70.9265 & 69.5305 & 0.20 & 47 & 70.0263 & 71.0277 & -0.23 \\
\hline 10 & 70.1550 & 67.9458 & -0.47 & 48 & 69.8149 & 71.2379 & -0.42 \\
\hline 11 & 70.1646 & 68.6168 & -0.23 & 49 & 69.6034 & 71.4437 & -0.59 \\
\hline 12 & 69.4972 & 69.3585 & -0.74 & 50 & 69.3918 & 71.6451 & -1.22 \\
\hline 13 & -69.0232 & 69.9852 & -1.01 & 51 & 69.1801 & 71.8424 & -1.67 \\
\hline 14 & 68.7638 & 70.0096 & -0.46 & 52 & 68.9683 & 72.0356 & -1.29 \\
\hline 15 & -71.5745 & 70.8000 & 1.60 & 53 & 72.0474 & 67.9686 & 1.95 \\
\hline 16 & -69.5594 & 73.4816 & 0.18 & 54 & 71.8390 & 68.2387 & 1.19 \\
\hline 17 & 70.3799 & 72.0702 & 0.57 & 55 & 71.6303 & 68.5026 & 0.79 \\
\hline 18 & 69.7410 & 72.6652 & 0.31 & 56 & 71.4213 & 68.7604 & 0.97 \\
\hline 19 & 69.5278 & 72.8551 & -0.23 & 57 & 70.5831 & 69.7353 & -0.43 \\
\hline 20 & 69.3146 & 73.0410 & 0.51 & 58 & 70.3731 & 69.9657 & -0.78 \\
\hline 21 & 72.2111 & 69.3321 & 3.29 & 59 & 70.1629 & 70.1912 & -1.05 \\
\hline 22 & 72.0006 & 69.5885 & 0.88 & 60 & 69.9525 & 70.4119 & -1.66 \\
\hline 23 & 71.7899 & 69.8390 & 0.64 & 61 & 69.7420 & 70.6279 & -0.79 \\
\hline 24 & 71.5790 & 70.0836 & 0.01 & 62 & 69.5313 & 70.8393 & -0.60 \\
\hline 25 & 71.3679 & 70.3226 & 0.25 & 63 & 69.3205 & 71.0464 & -0.66 \\
\hline 26 & 71.1566 & 70.5561 & 0.23 & 64 & 69.1095 & 71.2492 & -0.20 \\
\hline 27 & 70.9452 & 70.7844 & 0.32 & 65 & 68.8985 & 71.4478 & 0.36 \\
\hline 28 & 70.7335 & 71.0075 & 0.17 & 66 & 70.0860 & 69.5744 & 0.14 \\
\hline 29 & 70.5218 & 71.2258 & 0.41 & 67 & 69.8765 & 69.8008 & 0.37 \\
\hline 30 & 70.3098 & 71.4392 & -0.29 & 68 & 69.6668 & 70.0224 & -0.10 \\
\hline 31 & 70.0978 & 71.6480 & 0.63 & 69 & 69.4570 & 70.2394 & -0.70 \\
\hline 32 & 69.8856 & 71.8523 & 0.00 & 70 & 69.2470 & 70.4519 & -0.78 \\
\hline 33 & 69.6733 & 72.0523 & 0.10 & 71 & 69.0368 & 70.6600 & -0.32 \\
\hline 34 & 69.4609 & 72.2481 & -0.98 & 72 & 68.8266 & 70.8640 & -1.26 \\
\hline 35 & 69.2484 & 72.4397 & -1.24 & 73 & 68.8199 & 72.1684 & -1.42 \\
\hline 36 & 69.0359 & 72.6274 & -2.36 & 74 & 68.7508 & 71.5844 & 0.75 \\
\hline 37 & 72.1305 & 68.6472 & 0.50 & 75 & 68.6942 & 72.2797 & 1.57 \\
\hline
\end{tabular}

uncertainty of $\sim 5 \mathrm{~kg} \mathrm{~m}^{-3}$ (Wen and others, 2007). The uncertainty of sea-water density is probably $<2 \mathrm{~kg} \mathrm{~m}^{-3}$. Using these values, $\Delta Z / Z$ is $5.2 \%$. The relative ice-thickness differences between the hydrostatic estimates and borehole measurements are $2.7 \%$ at AM01 (with a borehole measured thickness of $479 \pm 2 \mathrm{~m}), 1.1 \%$ at AM02 (373 $\pm 2 \mathrm{~m}), 2.5 \%$ at AM03 $(722 \pm 2 \mathrm{~m})$ and $6.3 \%$ at AM04 $(603 \pm 2 \mathrm{~m})$ (Craven and others, 2004, 2009; personal communication from $\mathrm{M}$. Craven, 2009). This comparison with the in situ borehole measurements suggests that the estimated ice-thickness uncertainty of $5.2 \%$ is reasonable.

The errors involved in calculating the basal melting and freezing rates include the errors in ice thickness, ice velocity components, column-averaged ice density and annual net accumulation. The error of ice velocity components is estimated to be about $10 \mathrm{ma}^{-1}$. Uncertainties of ice fluxes $\left(\Phi_{x}, \Phi_{y}\right)$ were estimated to be about $10 \%$. Over the northern portion of the Amery Ice Shelf, the uncertainty of the basal melting/freezing rate is possibly up to $0.5 \mathrm{ma}^{-1}$, and the error of annual net accumulation could make an important contribution to the errors of basal melting and freezing rates where they are smaller than $\pm 0.5 \mathrm{~m} \mathrm{a}^{-1}$. Over the southern portion, the uncertainty of annual net accumulation is insignificant compared to the basal melting rate, and the uncertainty of the basal melting/freezing rate is possibly up to $20 \%$, mainly due to the errors in ice-thickness and icevelocity components. An overall uncertainty of $15 \%$ is assumed for the total basal melting and freezing.

Although the trend of elevation change over the Amery Ice Shelf between 1968 and 2007 is not significantly different from zero, there have been two shorter periods of average elevation change exceeding $\pm 0.1 \mathrm{ma}^{-1}$ (King and others, 2009). The velocity may also have slowed slightly $\left(\sim 2.2 \mathrm{~m} \mathrm{a}^{-1}\right.$ or $\left.\sim 0.6 \%\right)$ between 1968 and 1999 (King and others, 2007). Over the 4 year time-span (2000-04) between the InSAR velocity data acquisition and ICESat-DEM data acquisition, elevation and velocity changes may have respectively reached about 0.4 and $8.8 \mathrm{~m} \mathrm{a}^{-1}$ if the trends were the same as before 2000. These changes have an insignificant effect on the estimate of the basal melting and 
freezing, since they are systematic changes and relatively small compared with the elevation (typically $100 \mathrm{~m}$ ) and ice velocity (typically $>300 \mathrm{~m} \mathrm{a}^{-1}$ ) over the ice shelf.

\section{RESULTS AND DISCUSSION}

The total area of net melting under the Amery Ice Shelf is about $34700 \mathrm{~km}^{2}$ (Fig. 6). The melting rate has a maximum value of $25.0 \pm 4.0 \mathrm{~m} \mathrm{a}^{-1}$ averaged over an area of $180 \mathrm{~km}^{2}$ near the southern grounding line and decreases rapidly downstream. Basal freezing primarily occurs beneath the northwest part of the ice shelf. The total area of net freezing is about $26100 \mathrm{~km}^{2}$, and the area-averaged freezing rate can be as high as $2.4 \pm 0.4 \mathrm{~m} \mathrm{a}^{-1}$. The total basal melting under the entire ice shelf is $62.5 \pm 9.3 \mathrm{Gta}^{-1}$, and the total basal freezing is $16.1 \pm 2.4 \mathrm{Gta}^{-1}$, giving a total net basal mass loss of $46.4 \pm 6.9 \mathrm{Gta}^{-1}$.

When the melting/freezing rates were calculated on $20 \mathrm{~km} \times 20 \mathrm{~km}$ squares, the total area of net melting was $33700 \mathrm{~km}^{2}$, with total basal melting of $62.2 \mathrm{Gt} \mathrm{a}^{-1}$. The total area of net freezing was $27100 \mathrm{~km}^{2}$, with total basal freezing of $17.6 \mathrm{Gta}^{-1}$. The total net mass loss was $44.6 \mathrm{Gt}$ $\mathrm{a}^{-1}$. The distribution of melting and freezing is very similar to that in Figure 6, with some small differences mostly around the edges of the ice shelf. This indicates that our results are relatively insensitive to the size of the squares over which the melting/freezing rate calculations are performed.

For the whole Lambert Glacier/Amery Ice Shelf system, which includes Antarctic drainage basins 9, 10 and 11, as defined by Giovinetto and Zwally (2000), the ice flux across the grounding line onto the ice shelf is $88.9 \pm 8.9 \mathrm{Gt} \mathrm{a}^{-1}$ (Wen and others, 2008). From the modified Giovinetto compilation, the mean annual accumulation rate over the whole Amery Ice Shelf surface is $162 \mathrm{~kg} \mathrm{~m}^{-2} \mathrm{a}^{-1}$, giving a total accumulation of $9.8 \pm 1.0 \mathrm{Gta}^{-1}$. The ice fluxes, $\Phi$, were calculated for three flux gates at the ice-shelf front according to Equation (4). The total ice flux across the gates at the iceshelf front is $47.2 \pm 3.6 \mathrm{Gta}^{-1}$. If the Amery Ice Shelf is in steady state, then total net basal melting of $51.5 \pm 9.6 \mathrm{Gt} \mathrm{a}^{-1}$ is required to balance the sum of the inflow and the integrated accumulation less the mass discharge. This is consistent with the net basal melting of $46.4 \pm 6.9 \mathrm{Gt} \mathrm{a}^{-1}$ estimated above.

The freezing beneath the Amery Ice Shelf is distributed within the northwest of the ice shelf (Fig. 6), which is consistent with the marine ice distribution mapped previously by Fricker and others (2001) and Wang and others (2006). The freezing area mapped from this research is $26100 \mathrm{~km}^{2}$, and the area of marine ice from Wang and others (2006) is $26400 \mathrm{~km}^{2}$. The thickest marine ice forms two longitudinal bands, oriented along the ice-flow direction. The distribution of the maximum freezing rates (marked with $A$ and $B$ in Fig. 6) corresponds to the locations of the thickest marine ice, where the freezing rates range between $1.5 \pm 0.2$ and $2.4 \pm 0.4 \mathrm{~m} \mathrm{a}^{-1}$. The freezing rates between the two longitudinal bands are relatively low, and slight melting is detected in one patch, though the melting rates are $<0.5 \mathrm{~m} \mathrm{a}^{-1}$. This patch of melting is not consistent with the marine ice distribution, and may be caused by the combined errors in the ice thickness, the column-averaged ice density, annual net accumulation and velocity data, which may result in an uncertainty of the basal melting/freezing rate of up to $0.5 \mathrm{~m} \mathrm{a}^{-1}$. Based on the temperature and salinity gradients of the ocean/ice interface measured at $\mathrm{AM02}$, Craven and others (2004) estimated a minimum melting rate of $0.5 \mathrm{~m} \mathrm{a}^{-1}$, compared to our result of $0.3 \pm 0.2 \mathrm{~m} \mathrm{a}^{-1}$. Craven and others (2009) determined an average accretion rate of marine ice of $1.1 \pm 0.2 \mathrm{~m} \mathrm{a}^{-1}$ between AM01 and AM04, and inferred a similar average rate upstream of $1.3 \pm 0.2 \mathrm{~m} \mathrm{a}^{-1}$ between AM04 and JP (Fig. 1), with a reference density of $920 \mathrm{~kg} \mathrm{~m}^{-3}$. Our estimates at the corresponding locations are $0.86 \pm 0.2$ and $0.71 \pm 0.2 \mathrm{ma}^{-1}$, respectively.

Melting of $1.0-1.6 \mathrm{ma}^{-1}$ near the ice front (Fig. 6) is caused by tidal pumping and the seasonally warmer waters of the coastal current (Jacobs and others, 1992). It varies, however, along the ice front from east to west. At the front of the thick bands of accreted marine ice, the extent and magnitude of melting is smaller or zero. The sub-freezing iceshelf water beneath the bands possibly mitigates the melting associated with the tidal pumping (Wen and others, 2007).

Our estimates for the total melting, freezing and net melting beneath the Amery Ice Shelf are considerably larger than the previous results from numerical simulations (Hellmer and Jacobs, 1992; Williams and others, 2001; Hellmer, 2004). These model estimates, however, all used a smaller and shallower sub-shelf cavity, based on the grounding line position of Budd and others (1982). The grounding line of the Amery Ice Shelf has been redefined and shifted about $240 \mathrm{~km}$ upstream (Fricker and others, 2002; Rignot, 2002). Modeling studies of simplified ice-shelf cavities by Holland and others (2008) show the strong effect of cavity shape on basal melting rates. Williams (1999) found that the melting and freezing pattern from a sub-iceshelf model varies significantly when the cavity is extended to that defined by Fricker and others (2002). The different dimensions of the sub-ice cavity as defined by the previous position of the grounding line are responsible for these smaller simulated values (Galton-Fenzi and others, 2008).

Melting processes beneath ice shelves are governed by the transport of ocean heat and by the sea-water freezing temperature (Doake, 1976). The ice draft at the grounding line location defined by Budd and others (1982) is only about $700 \mathrm{~m}$, whereas at the redefined southern grounding line it is $>2000 \mathrm{~m}$. The in situ sea-water freezing point is lower at greater depth, and the difference between this and the ocean temperature is greater, resulting in a higher melting rate. From our present study the area-averaged melting rate is up to $25 \pm 4.0 \mathrm{~m} \mathrm{a}^{-1}$ at the redefined grounding line, which is similar to the $31 \pm 5 \mathrm{~m}$ ice $\mathrm{a}^{-1}$ reported by Rignot and Jacobs (2002), whereas it is only $0.5-1.0 \mathrm{~m} \mathrm{a}^{-1}$ at the location given by Budd and others (1982). More than $80 \%$ of the continental ice from Lambert, Mellor and Fisher glaciers is lost through basal melting beneath the southernmost $240 \mathrm{~km}$ of the Amery Ice Shelf (Wen and others, 2007; Craven and others, 2009).

Our estimate of the net melting beneath the shelf is also larger than that estimated from oceanographic measurements in Prydz Bay (Wong and others, 1998). A possible reason for this difference is the small number of hydrographic measurements across the ice-shelf front available to Wong and others (1998), and seasonal and interannual variability in the melting rate.

\section{CONCLUSIONS}

We have assessed the distribution of basal melting and freezing rates under the Amery Ice Shelf by integrating a variety of datasets. Our results show that the areal extents of the basal melting and freezing under the ice shelf are 34700 and $26100 \mathrm{~km}^{2}$, respectively. The average melting rate over 
the melting region is $\sim 1.8 \pm 0.3 \mathrm{~m} \mathrm{a}^{-1}$, and the maximum melt rate is $\sim 25.0 \pm 4.0 \mathrm{~m} \mathrm{a}^{-1}$ (averaged over an area of $180 \mathrm{~km}^{2}$ ) under the deepest ice near the southern grounding line. The total amount of melt is $62.5 \pm 9.3 \mathrm{Gta}^{-1}$. Basal freezing is located in the northwest region of the ice shelf, and the highest freezing rate is $2.4 \pm 0.4 \mathrm{~m} \mathrm{a}^{-1}$. The total basal accretion of marine ice is estimated to be $16.2 \pm 2.4$ $\mathrm{Gta}^{-1}$. The total net loss of mass beneath the ice shelf is $46.4 \pm 6.9 \mathrm{Gta}^{-1}$, which is consistent with the difference $\left(51.5 \pm 10.1 \mathrm{Gta}^{-1}\right)$ between mass input to the ice shelf (the sum of inland ice inflow plus the total surface accumulation on the ice shelf) and mass output through the ice-shelf front.

A map of the melting and freezing rates was generated using a kriging interpolation method. This map shows that the basal freezing and corresponding basal marine ice are characterized by the two longitudinal bands along the iceflow direction. This pattern is in agreement with the marine ice distribution mapped by Fricker and others (2001) and Wang and others (2006). The net melting accounts for about $50 \%$ of the total mass loss from the ice shelf. This is far greater than a typical ratio (about $30 \%$ ) of the basal melting to the total mass loss for ice shelves (Jacobs and others, 1996). Basal melting and freezing under the Amery Ice Shelf play a critical role in the ice-shelf mass balance, and the interaction at the ice/ocean interface beneath the ice shelf may be more intensive than was thought previously.

\section{ACKNOWLEDGEMENTS}

This work was supported by the National Natural Science Foundation of China through grants 40871035 and 40730526, the Shanghai Municipal Education Commission, the Shanghai Education Development Foundation through grants 05SG46 and S30406, and the Leading Academic Discipline Project of Shanghai Normal University through grant DZL801. K. Jezek was partially supported by the Center for Remote Sensing of Ice Sheets (CReSIS), University of Kansas. Jiahong Wen expresses gratitude to the Antarctic Climate and Ecosystems Cooperative Research Centre for hosting a visit to Hobart to complete the paper. We also thank M.B. Giovinetto for providing accumulation compilations, R. Coleman, N. Young, H.A. Fricker, J. DiMarzio and M. Craven for providing the geoid model, grounding line, DEM and in situ GPS and accumulation data over the Amery Ice Shelf, and R. Warner for valuable suggestions. Constructive comments and suggestions from M. King and two anonymous reviewers have been very helpful in improving this paper.

\section{REFERENCES}

Allison, I. 2003. The AMISOR project: ice shelf dynamics and iceocean interaction of the Amery Ice Shelf. FRISP Rep. 14, 74-82.

Budd, W. 1966. The dynamics of the Amery Ice Shelf. J. Glaciol., 6(45), 335-358.

Budd, W.F., M.J. Corry and T.H. Jacka. 1982. Results from the Amery Ice Shelf Project. Ann. Glaciol., 3, 36-41.

Craven, M. and 6 others. 2004. Initial borehole results from the Amery Ice Shelf hot-water drilling project. Ann. Glaciol., 39, 531-539.

Craven, M. and 7 others. 2005. Borehole imagery of meteoric and marine ice layers in the Amery Ice Shelf, East Antarctica. J. Glaciol., 51(172), 75-84.

Craven, M., I. Allison, H.A. Fricker and R. Warner. 2009. Properties of a marine ice layer under the Amery Ice Shelf, East Antarctica. J. Glaciol., 55(192), 717-728.
De Angelis, H. and P. Skvarca. 2003. Glacier surge after ice shelf collapse. Science, 299(5612), 1560-1562.

Doake, C.S.M. 1976. Thermodynamics of the interaction between ice shelves and the sea. Polar Rec., 18(112), 37-41.

Domack, E. and 9 others. 2005. Stability of the Larsen B ice shelf on the Antarctic Peninsula during the Holocene epoch. Nature, 436(7051), 681-685.

Fricker, H.A., G. Hyland, R. Coleman and N.W. Young. 2000. Digital elevation models for the Lambert Glacier-Amery Ice Shelf system, East Antarctica, from ERS-1 satellite radar altimetry. J. Glaciol., 46(155), 553-560.

Fricker, H.A., S. Popov, I. Allison and N. Young. 2001. Distribution of marine ice under the Amery Ice Shelf, East Antarctica. Geophys. Res. Lett., 28(11), 2241-2244.

Fricker, H.A. and 9 others. 2002. Redefinition of the Amery Ice Shelf, East Antarctica, grounding zone. J. Geophys. Res., 107(B5), 2092. (10.1029/2001JB000383.)

Galton-Fenzi, B.K., C. Maraldi, R. Coleman and J. Hunter. 2008. The cavity under the Amery Ice Shelf, East Antarctica. J. Glaciol., 54(188), 881-887.

Giovinetto, M.B. and H.J. Zwally. 2000. Spatial distribution of net surface accumulation on the Antarctic ice sheet. Ann. Glaciol., 31, 171-178.

Hellmer, H.H. 2004. Impact of Antarctic ice shelf basal melting on sea ice and deep ocean properties. Geophys. Res. Lett., 31(10), L10307. (10.1029/2004GL019506.)

Hellmer, H.H. and S.S. Jacobs. 1992. Ocean interactions with the base of Amery Ice Shelf, Antarctica. J. Geophys. Res., 97(C12), 20,305-20,317.

Holland, P.R., A. Jenkins and D.M. Holland. 2008. The response of ice shelf basal melting to variations in ocean temperature. J. Climate, 21(11), 2558-2572.

Jacobs, S.S., H.H. Hellmer, C.S.M. Doake, A. Jenkins and R.M. Frolich. 1992. Melting of ice shelves and the mass balance of Antarctica. J. Glaciol., 38(130), 375-387.

Jacobs, S.S., H.H. Hellmer and A. Jenkins. 1996. Antarctic ice sheet melting in the southeast Pacific. Geophys. Res. Lett., 23(9), 957-960.

Jenkins, A. and C.S.M. Doake. 1991. Ice-ocean interaction on Ronne Ice Shelf, Antarctica. J. Geophys. Res., 96(C1), 791-813.

Jezek, K.C. 1999. Glaciological properties of the Antarctic ice sheet from RADARSAT-1 synthetic aperture radar imagery. Ann. Glaciol., 29, 286-290.

Jezek, K.C. 2002. RADARSAT-1 Antarctic Mapping Project: changedetection and surface velocity campaign. Ann. Glaciol., 34, 263-268.

Jezek, K.C. 2003. Observing the Antarctic ice sheet using the RADARSAT-1 synthetic aperture radar. Polar Geogr., 27(3), 197-209.

Jezek, K.C. 2008. The RADARSAT-1 Antarctic Mapping Project. Columbus, $\mathrm{OH}$, The Ohio State University. Byrd Polar Research Center. (BPRC Report No. 22.)

Joughin, I. 2002. Ice-sheet velocity mapping: a combined interferometric and speckle-tracking approach. Ann. Glaciol., 34, 195-201.

Joughin, I. and L. Padman. 2003. Melting and freezing beneath Filchner-Ronne Ice Shelf, Antarctica. Geophys. Res. Lett., 30(9), 1477-1480.

King, M.A. 2002. The dynamics of the Amery ice shelf from a combination of terrestrial and space geodetic data. (PhD thesis, University of Tasmania.)

King, M.A., R. Coleman, P.J. Morgan and R.S. Hurd. 2007. Velocity change of the Amery Ice Shelf, East Antarctica, during the period 1968-1999. J. Geophys. Res., 112(F1), F01013. (10.1029/ 2006JF000609.)

King, M.A. and 7 others. 2009. A 4-decade record of elevation change of the Amery Ice Shelf, East Antarctica. J. Geophys. Res., 114(F1), F01010. (10.1029/2008JF001094.)

Mellor, M. and G. McKinnon. 1960. The Amery Ice Shelf and its hinterland. Polar Rec., 10(64), 30-34. 
Monaghan, A.J. and 15 others. 2006. Insignificant change in Antarctic snowfall since the International Geophysical Year. Science, 313(5788), 827-831.

Morgan, V.I. 1972. Oxygen isotope evidence for bottom freezing on the Amery Ice Shelf. Nature, 238(5364), 393-394.

Oppenheimer, M. 1998. Global warming and the stability of the West Antarctic ice sheet. Nature, 393(6683), 325-332.

Payne, A.J., A. Vieli, A. Shepherd, D.J. Wingham and E. Rignot. 2004. Recent dramatic thinning of largest West Antarctic ice stream triggered by oceans. Geophys. Res. Lett., 31(23), L23401. (10.1029/2004GL021284.)

Pritchard, H.D., R.J. Arthern, D.G. Vaughan and L.A. Edwards. 2009. Extensive dynamic thinning on the margins of the Greenland and Antarctic ice sheets. Nature, 461(7266), 971-975.

Rignot, E.J. 1998. Fast recession of a West Antarctic glacier. Science, 281(5376), 549-551.

Rignot, E. 2001. Evidence for rapid retreat and mass loss of Thwaites Glacier, West Antarctica. J. Glaciol., 47(157), 213-222.

Rignot, E. 2002. Mass balance of East Antarctic glaciers and ice shelves from satellite data. Ann. Glaciol., 34, 217-227.

Rignot, E. and S.S. Jacobs. 2002. Rapid bottom melting widespread near Antarctic ice sheet grounding lines. Science, 296(5575), 2020-2023.

Rignot, E., G. Casassa, P. Gogineni, W. Krabill, A. Rivera and R. Thomas. 2004. Accelerated ice discharge from the Antarctic Peninsula following the collapse of Larsen B ice shelf. Geophys. Res. Lett., 31(18), L18401. (10.1029/ 2004GL020697.)

Scambos, T., C. Hulbe and M. Fahnestock. 2003. Climate-induced ice shelf disintegration in the Antarctic Peninsula. In Domack, E.W., A. Burnett, A. Leventer, P. Conley, M. Kirby and R. Bindschadler, eds. Antarctic Peninsula climate variability: a historical and paleoenvironmental perspective. Washington, DC, American Geophysical Union, 79-92. (Antarctic Research Series 79.)

Scambos, T.A., J.A. Bohlander, C.A. Shuman and P. Skvarca. 2004. Glacier acceleration and thinning after ice shelf collapse in the Larsen B embayment, Antarctica. Geophys. Res. Lett., 31(18), L18402. (10.1029/2004GL020670.)
Shepherd, A., D. Wingham and E. Rignot. 2004. Warm ocean is eroding West Antarctic Ice Sheet. Geophys. Res. Lett., 31(23), L23404. (10.1029/2004GL021106.)

Thomas, R. and 17 others. 2004. Accelerated sea-level rise from West Antarctica. Science, 306(5694), 255-258.

Vaughan, D.G. and C.S.M. Doake. 1996. Recent atmospheric warming and retreat of ice shelves on the Antarctic Peninsula. Nature, 379(6563), 328-331.

Vaughan, D.G., J.L. Bamber, M.B. Giovinetto, J. Russell and A.P.R. Cooper. 1999. Reassessment of net surface mass balance in Antarctica. J. Climate, 12(4), 933-946.

Wang, Y., J. Wen, J. Liu, K. Jezek and B. Csatho. 2006. Amery ice shelf DEM and its marine ice distribution. Chinese J. Polar Sci., 17(2), 117-123.

Wen, J., K.C. Jezek, B. Csatho, U.C. Herzfeld, K.L. Farness and P. Huybrechts. 2007. Mass budgets of the Lambert, Mellor and Fisher Glaciers and basal fluxes beneath their flowbands on Amery Ice Shelf. Sci. China D, 50(11), 1693-1706.

Wen, J. and 7 others. 2008. Mass budget of the grounded ice in the Lambert Glacier-Amery Ice Shelf system. Ann. Glaciol., 48 , 193-197.

Williams, M.J.M. 1999. A numerical study of ocean circulation and ice-ocean interaction beneath the Amery Ice Shelf, Antarctica. (PhD thesis, University of Tasmania.)

Williams, M.J.M., K. Grosfeld, R.C. Warner, R. Gerdes and J. Determann. 2001. Ocean circulation and ice-ocean interaction beneath the Amery Ice Shelf, Antarctica. J. Geophys. Res., 106(C10), 22,383-22,399.

Wong, A.P.S., N.L. Bindoff and A. Forbes. 1998. Ocean-ice shelf interaction and possible bottom water formation in Prydz Bay, Antarctica. In Jacobs, S.S. and R.F. Weiss, eds. Ocean, ice, and atmosphere: interactions at the Antarctic continental margin. Washington, DC, American Geophysical Union, 173-187. (Antarctic Research Series 75.)

Xiao, C., J. Ren, D. Qin, H. Li, W. Sun and I. Allison. 2001. Correspondence. Complexity of the climatic regime over the Lambert Glacier basin of the East Antarctic ice sheet: firn-core evidences. J. Glaciol., 47(156), 160-162.

Young, N.W. and G. Hyland. 2002. Velocity and strain rates derived from InSAR analysis over the Amery Ice Shelf, East Antarctica. Ann. Glaciol., 34, 228-234. 